\title{
健康増進型保険が保険事業に与える 影響について
}

\section{安井 敏 晃}

\section{ロアブストラクト}

本格的な健康増進型保険がわが国で販売されてからすでに数年が経過して いる。この保険が登場した背景には ICT の発達により被保険の健康に関す るデータの捕捉と分析が容易になったことがある。この保険が発達すること により謝絶体の減少と保険体の増加，危険標識の再考等の影響が考えられる。 またITCの進展は今後，人保険におけるリスク細分化のあり方にも影響を 及ぼすことになろう。

\section{ロキーワード}

健康増進型保険，リスク細分化，私保険

\section{はしがき}

健康増進型保険がわが国でも各社から販売され，関心を集めている。これ らの健康増進型保険の中には，携帯端末などの電子機器により被保険者のフ イットネス活動をリアルタイムで捕捉し，その情報を保険料に反映させるも のもある。

この健康増進型保険は，保険事業に様々な影響をもたらすと予想されてい る InsureTechの一例である。その影響は単に保険事業を効率化させるにと どまらず，保険事業そのものを変革させる可能性を持つ。それがもたらす影

* 令和元年10月27日の日本保険学会大会（関西大学）報告による。

/ 令和 2 年 3 月 27 日原稿受領。 
健康増進型保険が保険事業に与える影響について

響については様々な予測があるが, その中には保険事業の構造自体が変化し てアンバンドリング化・リバンドリング化が進展するなど比較的穏当なもの から，保険事業の中心から既存の保険企業が閉め出されるとするものさえあ る ${ }^{1)}$ 。保険企業の撤退は極端としても, 従来保険企業がそれぞれ一社で行っ ていた業務の中には，他業態と共同する業務や，アウトソーシングする業務 がますます増加するものと思われる。例えばわが国でもドコモやディー・エ ヌ・エーがヘルスケア事業に参入して, 保険事業に利用可能な健康情報デー

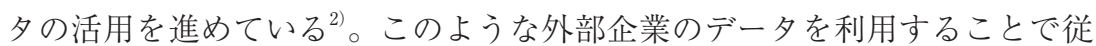
来にない商品の開発が期待できる。事実，海外の企業と提携することで，こ れまで得られなかった情報をもとに保険商品開発をしている企業もある3)。

医療情報についてはIoMTという概念さえ提唱されている。これは 「Internet of Medical Things の略で, 医療機器とヘルスケアのITシステム をオンラインのコンピューターネットワークを通じてつなぐという概念で」 ある ${ }^{4)}$ 。医療機器がつながり, ビッグデー夕の解析が進むと, 被保険者のデ ータ・行動から, 疾病・死亡リスクをより正確に予測できるようになろう。

さて, このようなビッグデータの分析が進展することにより, 消費者側に とってデメリットとなる場合も指摘されている5)。これまで利用できなかっ た健康関連指標と罹病率，死亡率などの相関が明らかになることにより，保 険料率が高くなるだけでなく，保険に加入できなくなる被保険者が現れると いう懸念である。もつとも，現在までの動向を見る限り，今後も消費者の保 険へのアクセスを狭めるだけの結果にはならないものと思われる。本稿では 健康増進型保険が保険事業に与える影響について検討してみたい。

1） IAIS (2017), 大和総研編著 (2018), pp.368-370., BCG (2018), pp.6-10。

2）永田監訳 (2017), p.65。

3）後述する住友生命とディスカバリー社の提携によるVitarity である。

4）IoMT 学会ウェブページ (https://iomt.or.jp, 10/19 閲覧)。

5）加藤 ·桜井 (2016), p. 188., 上野 (2019), p. 116。 


\section{1. 健康への高い関心}

健康増進型保険について検討する前に，わが国における健康への関心の高 さを確認しておきたい。わが国では健康に対する関心が高く，テレビの CM で健康関連の商品を見ない日はないと言ってよいほどである。健康に不安を 持つ消費者も多い。例えば内閣府の調査において, 日頃の生活の中で悩みや 不安を問う質問に対して「悩みや不安を感じている」との回答は $63.0 \%$ 占 める。さらに悩みや不安の内容を尋ねると,「自分の健康について」との回 答が $54.5 \%$ 占め,「家族の健康について」と回答した割合も $42.2 \%$ 占め ていた（「国民生活に関する世論調査（2018年）」)。

健康増進型保険導入の背景としては，消費者の関心だけでなく，企業経営 や政府の取り組みがあることが指摘されている ${ }^{6)}$ 。企業の取り組みの中では, 特に「健康経営」が注目されよう。この健康経営の意味するところは論者に より多少異なるが，経済産業省によるとこれは「従業員等の健康保持・増進 の取り組みが，将来的に企業の収益性等を高める投資であるとの考えのもと， 従業員等の健康管理を経営的な視点から考え, 戦略的に取り組むこと」とさ れる7)。この用語自体は登録商標とされており，岡田によるとこれは，「利 益を創出するための経営管理と, 生産性や創造性向上の源である働く人の心 身の健康の両立をめざして, 経営の視点から投資を行い（健康投資），企業 内事業として起業しその利益を創出すること」となる8)。

政府もこの健康経営を支援しており, 経済産業省と東京証券取引所が共同 して「健康経営銘柄」を選定している。この制度は優れた健康経営の取り組 みを実施する企業を東京証券取引所の上場企業33業種から 1 業種 1 社ずつ選 定するものである。すでに 4 回実施されており，「健康経営銘柄2018」では
6) 熊沢 (2018a), pp.16-21。
7) 『健康経営銘柄2018』。
8）岡田 (2015), pp.10-11。 
健康増進型保険が保険事業に与える影響について

26業種26社が選定されている より健康経営度調査が行われているが, その項目の中に「従業員の健康保 持・増進における課題」が訊ねられている。その回答として「生活習慣病等 発生予防」をあげた企業は $51.4 \%$, 「生活習慣病等高リスク者 重症化予防」 をあげている企業は $32.8 \%$ にんでいる。

このような健康増進の要求に応えるように, 各種ヘルスケア事業が発達し てきている。日本総合研究所の調査によると，2016年(度)時点でヘルスケア 産業（健康保持・増進に働きかけるもの）の市場規模は2016年で 9 兆1700億 円，また保険や患者/要支援・要介護者向けの商品・サービスを含むへルス ケア産業（患者/要支援・要介護者の生活を支援するもの）は24兆9400億円 と推計されているため, 合計すると34兆1100億円程度と巨額におよんでい $ろ^{10)}$ 。

政府は前述の他にも健康対策を盛んに進めている。2000年以降の主立った 動きを概観しておきたい。まず同年における「21世紀における国民健康づく り運動（健康日本21）」の開始（2012年終了）, 2002年の健康増進法の成立, 2008年の「高齢者医療確保法」の成立，同法による特定健康診査事業の開始 などがある。このうち，健康増進法ではその第二条において，「国民は，健 康な生活習慣の重要性に対する関心と理解を深め，生涯にわたって，自らの 健康状態を自覚するとともに，健康の増進に努めなければならない」と規定 されている。2010年にはわが国の成長戦略として「新成長戦略」が閣議決定 された。ここでは，「強い経済」「強い財政」「強い社会保障」の実現が目標 として掲げられ，それを実現するために「ライフ・イノベーション」による 健康大国の実現が示されている。2013年からは健康日本21（第二次）が開始 されている。このように，わが国においては国民の健康に高い関心がもたれ るだけでなく，政策的にもその増進が求められている。健康増進活動は疾病

9）経済産業省 HP。

10）日本総合研究所（2018）『平成29年度健康寿命延伸産業創推進事業（健康経 営普及推進 ·環境整備等事業) 調査報告書』。 
予防と表裏一体のものであり，これが進められることで，医療費の節減も期 待される ${ }^{11)}$ 。

さらに, これらの健康増進活動が必要とされるそもそもの前提として, わ が国の疾病構造の変化があることを確認しておきたい。多くの先進国と同様 に，死因の多くが感染症であった時代はすぎ（結核が1970年時点でまだ $2 \%$ を超えていたのはその名残である)，現在では死因の約 6 割を生活習慣病 （悪性新生物，糖尿病，高血圧性疾患，心疾患，脳血管疾患）が占めている のである ${ }^{12)} 。 こ の$ 生活習慣病とはかつて成人病と呼ばれてきた一連の疾病を 言い換えた用語である ${ }^{13)}$ 。これらの疾病は，加齢に伴い罹患率が高くなるが， その発症・進行には個々人の生活習慣が深く関わっている。そこで，それら を改善することにより「疾病の発症・進行を予防できるという認識を国民に 醸成し, 行動に結びつけていくため」, 生活習慣に基づく疾病概念が必要と されたのである ${ }^{14)}$ 。まり，生活習慣病はその用語の成立からしてすでに予 防するための努力が期待されているのである ${ }^{15)}$ 。

11）厚生労働省（2013）『『国民の健康寿命が延伸する社会』に向けた予防・健康 管理に係る取組の推進について』。同資料によると, これらの取組の推進によ り，5兆円規模の医療費・介護費の効果額を目指すとある。

12）ただし，これらの疾患には生活習慣病の範疇に該当しないものもある。なお 残念なことに2020年になり, わが国でも再び感染症が猛威をふるうこととなっ た。

13）塚原 (1997), p. 69。

14）公衆衛生審議会（1996）。

15）前述の健康日本21（第二次）にある身体活動の目標をみると，例えば，20歳 ～64歳の男性では一日9,000歩, 女性では同じく8,500歩と具体的に示されてい る。 
健康増進型保険が保険事業に与える影響について

\section{死因年次推移分類別にみた死亡数の年次推移}

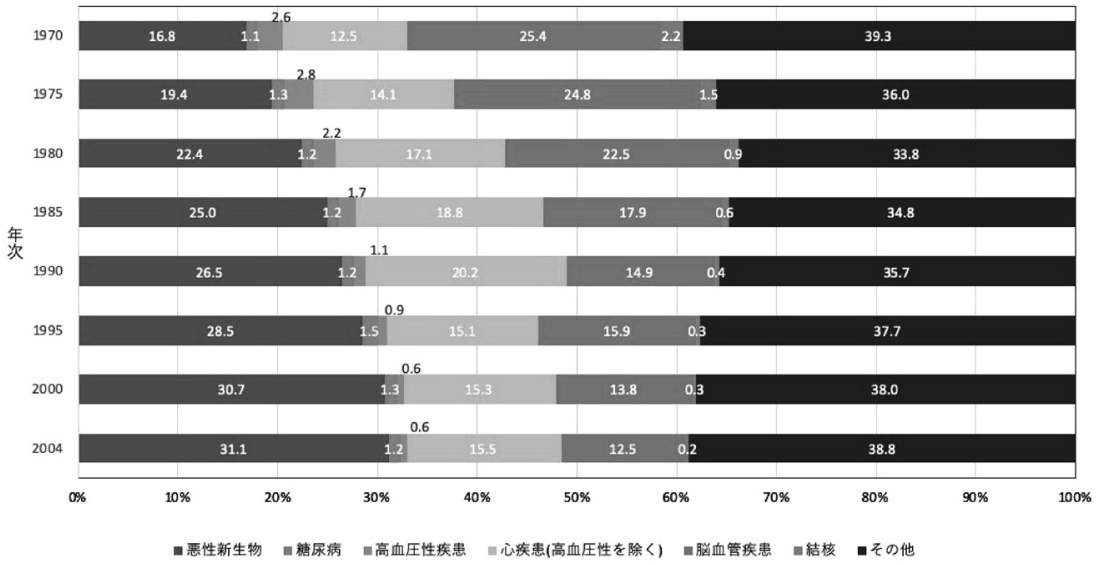

出典：厚生労働省「死因年次推移分類別にみた性別死亡数の年次推移」『平成21年 (2009) 人口動態統計（確定数）の概況』をもとに作成

\section{2. 健康増進型保険の現状}

この健康増進型保険は，わが国では2016年に販売されて以降，すでに複数 の企業から販売されている ${ }^{16)}$ 。それら健康増進型保険として扱われる保険の 保障内容を見ると, 医療保障や死亡保障, 就労不能の保障など人保険に含ま れる保障内容全般に及んでいる。もつとも，これらの保障が組み达まれてい る複雑な構成のものもある。また，健康状態により保険料が実質的に割引さ れることが特徵であるが，その条件には各社毎に違いが見られる。

例えば契約時に健康診断書を提出することで保険料が割引かれるシンプル

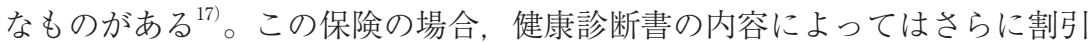

16）東洋経済社が調査したネオファースト生命，第一生命損保ジャパンひまわり 生命, 住友生命, 明治安田生命の各社が販売した健康増進型保険の累計件数を 単純に合計すると2019年 7 月時点で120万件を超えている。ただし各社により カウントの基準が異なるとの注記がある（東洋経済（2019）, p.21）。

17）第一生命保険の「検診割」。 
がある。同様の保険としては, 毎年健康診断書を提出し, その結果によって その都度保険料の一部が払い戻されるものがある ${ }^{18)}$ 。コンセプトは同じであ るが，より複雑なものとしては健康診断で計測される血圧，血糖值，BMI などの数值から健康状態を反映した「健康年齢」という年齢を算出し, 実年 齢ではなくこの年齢に基づき保険料を決定するという保険がある ${ }^{19)}$ 。

被保険者に明示的に運動を要求するものとしては, 例えば計測機器で歩数 を把握し，一定の基準を超えた場合に還付金が支払われる医療保険がある ${ }^{20)}$ 。 さらに本格的な健康増進型保険としては, 健康診断等各種検診の受診や運動 によってポイントが付与され，所定のポイントに達した場合に保険料が割引 となる保険がある。運動内容はウェアラブル端末やスマホなどで記録する。 この保険の場合，達成できないままでいるといずれは保険料が割増になるか

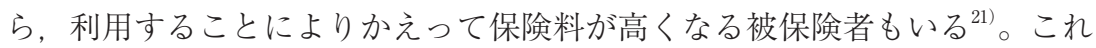
らは，テレマティクス自動車保険のように，電子機器により被保険者の行動 を把握し，それを保険料に反映するという点で，近年の ITCの発達により 可能となったものである。

これらの健康増進型保険の特徵を踏まえて, 本稿ではとりあえず健康増進 型保険を次のように理解しておきたい。すなわち，被保険者が，自身の健康 状態や健康増進の努力をエビデンスにもとづき示すことにより保険料が実質 的に割引かれる人保険である。

18）明治安田生命の「健康サポート・キャッシュバック」。

19）健康年齢少額短期保険株式会社の「健康年齢少額短期保険」。なおこの「健 康年齢」は日本医療データセンターの登録商標である。

20）東京海上日動あんしん生命社の「あるく保険」。

21）住友生命社の Vitality である。この保険ではこの健康プログラムを利用する にあたり，所定の保険料に加えてプログラムの利用料を払う。ただし，プログ ラムを利用する場合には利用しない場合に比べて15\%保険料が割り引かれる。 同社の保障内容には，死亡保障，介護補償，収入補償，医療保障がある。 


\section{3. 健康増進型保険の特徵}

この健康増進型保険は，健康状態や健康増進の努力によりリスクが細分化 されるため, 加入する被保険者は, 加入後に健康の維持・改善をはかる意思 がある者である。特に，前述のように維持・改善に失敗した場合に保険料が 高くなるタイプの保険では，意思の強い被保険者が加入することになろう。 健康増進活動の意欲だけでなく, 継続に自信がもてない被保険者はあえて健 康増進型保険に加入することはないと考えられるので従来型の保険に加入す ることになる。

このため, 今後健康増進型保険（特に割増がある夕イプの保険）の人気が 非常に高まり，市場で大きなシェアを占める場合には，保険論の教えるとこ ろでは従来型の保険において逆選択が生じることになる。逆選択を防止する ためには, 従来型の保険も健康増進型保険に移行することになろう。健康増 進活動を行う者と行わない者との間でリスク細分化がすすむことになる。細 分化が進むことになると，これまでは優良危険に紛れて内部補助を受けた被 保険者の保険料は高くなることになる22)。

言うまでもなくリスク細分化は優良危険には好ましいが, その反面高リス ク者の保険料率を引き上げる。もちろんこの差別化の進展は給付反対給付均 等の原則に合致する。同原則が別名保険技術的公正の原則ということからも わかるように保険技術的に公正であり，大量性要件を充足する限り，保険論

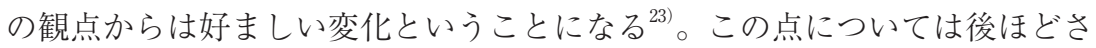
らに検討したい。

22）このような性質をもつため, 米山はこの保険について, テレマティクス自動 車保険と同じく,「マイナスのモラルハザード」の効果を持つ保険としている。 モラルハザードと正反対の効果であるから, この効果とは「保険契約後に, 契 約者の行動によって期待損失額（期待保険金支払コスト）が減少する」ことで ある(米山 (2017), pp.107-108)。

23）保険である以上，リスク細分化が進んでも大量性要件を充足させる必要があ る（水島 (2006), p. 24）。 
健康増進型保険は他にも興味深い特徵がある。前述のように健康増進活動 により保険料率が低くなることから，健康増進活動を促す保険である。この ため, 単なる保険ではなく, 健康増進活動（ロスコントロール）と危険負担 機能を併せ持つ一種のリスクマネジメント商品あるいはへルスケア商品と捉 える見方がある ${ }^{24)}$ 。

ヘルスケア商品と捉える場合には，フイットネス活動を行うメリットが被 保険者（消費者）に伝わりやすいから継続しやすいという点が長所として指 摘されている。フィットネス活動には消費者の努力が必要だからである ${ }^{25)} 。$ 体脂肪を減らし瘦せるためには，単に何かの商品を買うだけで目標を達成で きるわけではない。飲むだけで何もしなくて瘦せる薬などはない。ジムを利 用する場合には，入会金を払うだけでなく，実際にジムに通い，走るなり泳 ぐなり実際に努力しなければならない。瘦身を謳うダイエットプログラムを 購入する場合には，毎日の食事に気を使わねばならない。このように健康増 進のためには，ジムに通う，節制するなどの努力が消費者自身にも求められ る。そのため, 消費者が努力を続けられるようなインセンティブが必要とな るが, 健康増進型保険はこの点でも評価されているのである ${ }^{26)}$ 。努力するこ とにより保険料が低下する。それが達成できなくても，フィットネス活動で 一種のポイントがたまるため, ある種のゲームのような魅力がある。

さらにこの保険の特徴としては，ステータスシンボルとなりうるという点 を挙げることができよう。加入すること自体が，一種のステータスとなりう るのである。健康増進型保険に加入する被保険者は健康増進に強い関心を持 つはずである。特に実際に保険料を割引されるためには，頻繁にフィットネ ス活動を行うなど相当の努力が必要である。活動を続けるインセンティブが 与えられるとはいえ，保険料の割引に至るまで努力できる者は，かなり健康 増進に熱心な被保険者であるといえる。そのため, 健康増進保険で割引され

24）東洋経済 (2019), p.21., 熊沢 (2018a), p.23。

25）真野 (2005), p. 190。

26）加藤 (2018), p. 37。 
るということは健康への意識が高く，健康増進の努力を果たすことができる 被保険者であることの証明になりうる。

前述のようにわが国では消費者の健康に対する関心が高いだけでなく, 政 策としても健康増進が進められている。国民医療費が毎年増加しつづける状 況を考えると，この政策が転換されるとは考えづらい。官民あげて健康を希 求する風潮が続くならば，健康であることの評価はさらに高まるされること になろう。その場合には健康であることがある種のステータスとなりうる。 プラチナカードのようなグレードの高いクレジットカードを保有することが 社会的なステータスになるように，健康増進型保険に加入すること自体が一 種のステータスとなる可能性がある ${ }^{27)}$ 。

ヘルスデータ情報については，これを分析する企業が被保険者の健康の格 付けをなしうる可能性を肥塚が指摘する ${ }^{28)}$ 。このようなデー夕の分析を保険 会社自身が進めるならば，保険会社による被保険者の健康情報のスコアリン グは可能となる。もっとも，この情報は極めてセンシティブな情報なので, その利用には非常に厳格な制約を伴うことであろう。そのため, 健康データ の分析による健康格付けにまで保険企業が踏み込むと想定することは現実的 ではなからう。しかし保険に加入しているという事実, さらに保険料の割引 を享受しているという事実だけで，すでにその被保険者が健康であることの 証明となる。加入できる保険の種類によっては, 健康スコアを示すシグナル ともなる。こうなると保険業は「保障」を提供する企業というだけなく，一 種の信用情報をも提供するという点で「保証」をも提供する企業ともいうこ とになろう。

27）肥塚は，個人情報保護法上の問題は残るとしたうえで，火災保険を例に，保 険者の生活行動や習慣などをクレジットスコアとして評価し, それと火災の発 生率などの相関関係を見いだせればリスク評価の対象となることを指摘してい る(肥塚 (2019), pp.16-17)。

28）肥塚 (2019), p. 15。 


\section{4. ビッグデータの進展による加入条件の拡大}

健康増進型保険は InsureTech の一例であるが, InsureTech の進展によ り消費者にとり不利益をもたらす懸念が示されていた。ビッグデータの分析 により利用可能となった情報が利用されることで，保険加入が制限される消 費者が現れるという懸念である ${ }^{29)}$ 。将来的には健康増進型保険を含め，保険 業務に挍いてビッグデータを利用する際には，どの保険にも関係する問題で ある。まずこの影響を考えておきたい。

少なくとも現段階においては，加入が制限されたという動きはみられない。 むしろ想定に反して，ビッグデータの分析により，謝絶体の範囲が縮小する 事例が紹介されている ${ }^{30)}$ 。ビッグデータの解析が加入条件を広げているので ある。健康増進型保険というわけではないが，第一生命社ではすでに生命保 険の引き受け査定基準を緩和し，血糖值や肝機能等の基準を改定している。

このように科学技術の発達により加入条件が緩和された事例は, 生命保険 の歴史では珍しいものではない。例えば原始的な保険組織であるアミカブル ソサエティ（Amicable Society for a Perpetual Assurance Office）は加入者 を12歳から45歳の健康な者に限定していた ${ }^{31)}$ 。年齢を超えていたため, アミ カブルに加入を断られたと言われるシンプソンが近代的な生命保険会社であ るエクイタブル（The Society for Equitable Assurances on Lives and Survivorships）を創設したのは，保険史において有名なエピソードである ${ }^{32)} 。$ エクイタブルが生命表を用いるなど近代的な仕組みを整えることにより，ア ミカブルが排除した年齢層も生命保険に加入できるようになった ${ }^{33)}$ 。加入条 件が緩和された例は他にもある。19世紀末一20世紀初頭には保険医学の発達

29) 加藤 $\cdot$ 桜井 (2016), p. 188。

30）熊沢 (2018b), p. 38。武藤（2019）。

31）ブラウン (1983), pp.137-138。

32）ブラウン (1983), p.177。

33）ブラウン (1983), pp.178-179., 安井 (1997), pp.212-214。 
により，罹患後の予後の研究が進んだことで生命保険へ加入できる被保険者 は標準体から条件体にまで拡大することとなった ${ }^{34)}$ 。それまでは標準体に限

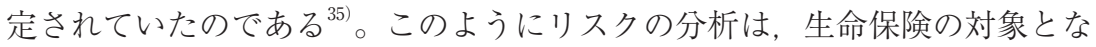
る被保険者を拡大させてきた歴史がある。

\section{5. 危険標識への影響}

さて, ITC 機器の進展により従来では確認できなかったデー夕を容易に 取得でき, 一方でビッグデータの分析が進展することになれば利用する危険 標識の顔ぶれは変わることとなろう。

例えば機器の例で言えば，現在健康増進型保険で端末機器により把握され る情報は，もっぱらフィットネス活動の成果が中心である。ヘルスケア産業 のデジタル化の進展は急であることから, 活用できる情報の高度化が予想さ れる。その候補となりうる機器がすでにある。採血をせずにセンサーにより

「血糖トレンドを継続的に把握することを可能にし」た機器がすでに実用化 されている ${ }^{36)}$ 。同様の機器を活用することにより, 疾病リスクや死亡リスク をさらに精緻に分析することができよう。

またビッグデータ分析の進展により, 罹病率や死亡率との相関のある新た な危険指標が発見されることは十分おこりうる。その場合には，これまで使 用されてきた危険標識が再検討される可能性があろう。従来から当然のよう に使用されてきた危険標識の中には，廃止される危険標識もあるはずであ る ${ }^{37)}$ 。前述したように，すでに現段階で販売されている健康増進型保険のな

34）日本保険医学会 (2003), p.27。

35）保険体は標準体および条件体からなる。一方，非保険体は謝絶体と契約延期 体からなる。

36）アボット社による，糖尿病患者向けグルコースモニタシステム「FreeStyle リ ブレ」(https://www.abbott.co.jp/media-center/press-releases/13-03-2020.html)。 37）必要がなくなったのではなく，利用が禁止された例に性別がある。EU 諸国 においては2004年の EU 指令により，保険料の算定にあたり性別を利用するこ とが禁止された。テレマティクス自動車保険が英国で販売された背景の一つに 
かには，実年齢ではなく「健康年齢」を用いて保険料率を決定する保険があ つた ${ }^{38)}$ 。新たに利用可能なビッグデータの解析によって, 現在より適切な危 険標識が利用可能となるのであれば，廃止される危険標識や，廃止されない にしてもその重要性が低下寸る危険標識があらわれるはずである。

もっとも精緻にリスクを細分化することができる危険指標といえども，す べて認められるわけではない。

損害保険では，わが国では損害保険料率算出団体に関する法律（料団法） の第 8 条で「料率団体の算出する参考純率及び基準料率は, 合理的かつ妥当 なものでなければならず，また，不当に差別的なものであつてはならない」 と定めている ${ }^{39)}$ 。同法は生命保険を規律するものではないが, 生命保険にお

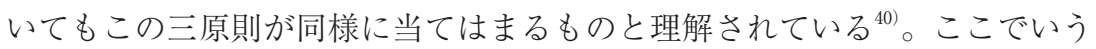
「合理的」とは保険料率が客観性があり精度も高い資料に基づき，保険数理 的に基づいた科学的方法で算出されることであり，「妥当」とは保険料率が 低すぎず，保険金の支払いに十分であることを意味している ${ }^{41}$ 。

問題となるのは「不当に差別的」でないという原則である。この意味は不 当でない差別（区別）は認められるという趣旨とされるが，そもそも不当に

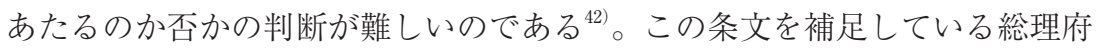

はこの性別利用の禁止があった。このことは危険標識の制限が，新たな危険標 識の活用を進めたともいえる。

38）もっとも健康年齢を算出するためには実年齢を知る必要あるから，実年齢が 保険料率に全く関係なくなるわけではない。

39）この原則は米国にならい導入された原則であり，わが国に固有のものではな い。例えば，ニューヨーク州保険法はその第2303条に抢いて次のように規定し ている。

Rates shall not be excessive, inadequate, unfairly discriminatory, destructive of competition or detrimental to the solvency of insurers.

40）生命保険新実務講座（1991）， p. 238。

41）石田 (2003), pp.45-47。なお，これらの要件は省令によりさらに詳細に規 定されている。

42) 石田 (2003), p.46。 
健康増進型保険が保険事業に与える影響について

令には「参考純率に係る危険の区分及び当該参考純率の水準が，当該危険の 区分の間の実態的な危険の格差に基づき適切に設定されていること」とある だけであり，何が不当にあたるかという基準までは明らかにされてはいない。 この点について石田は,「社会的に容認されるか否かが判断基準の一つとな ろう」とする ${ }^{43)}$ 。

これら料率三原則を守るのは当然であるが, 他の観点からも危険標識の妥 当性が問われる場合がある。米山は「道徳観」から禁止される危険標識とし て個人信用情報が自動車保険の危険標識として禁じられる例をあげ，その三 つの根拠を挙げている ${ }^{44)}$ 。それぞれ概略すると,「プライバシー利用の問題」, 「因果関係の存在が不明瞭であること」,「危険標識の利用が契約者の行動を 改善させないこと」の三つにまとめられよう。このうち, 因果関係が不明瞭 な場合は，前述の料率三原則にある「合理的」原則が適用されよう。

これらの道德観の観点も重要であるが, 健康増進型保険のような場合につ いては，米山は批判の可能性が少ないことを指摘している ${ }^{45)}$ 。確かに健康増 進型保険では，健康増進に向けた自助努力が保険料に反映される。健康活動 に積極的な被保険者が自助努力の結果，有利な保険料率を享受することは, 健康増進を進めるインセンティブを高めることになる ${ }^{46)}$ 。生活習慣病の患者 を減少させる政策を補完しているのであるから，批判されないというよりは， むしろ積極的に細分化が評価されると考えられるのではないか。

ただし，生活習慣病に関する危険標識については，契約者の行動が反映し ない標識があるので注意が必要である。生活習慣病といえども，生活習慣だ

43）石田（2003）, p.46。なお，不当であることが比較的わかりやすい場合もあ る。石田は同じ頁で人種差別や遺伝子による差別は, 統計的に有意な差があっ ても認められないとする。わが国では2020年段階においてもまだ利用されてい ない。

44）詳細は米山 (2017), pp.113-114。

45）もっとも，プライバシーの問題については懸念を示している。米山（2017）, pp. 113-114。

46）ニーハウス (2005), pp.226-227。 
けが必ずしもその病因ではない。前述の具申も生活習慣以外に遺伝要因（遺 伝子異常や加齢）と外部環境要因（病原体，有害物質，事故，ストレッサ 一）を挙げている ${ }^{47)}$ 。生活習慣が大きな影響を及ぼす糖尿病においても，近 年の研究では, 出生時体重と成人以降の発症率と強い相関があることが明ら かとなっている ${ }^{48)}$ 。同様の分析が進み，自助努力による改善が期待できない 新たな危険指標が取り入れられた場合には，消費者による細分化への抵抗も 大きいことになろう。もっとも健康増進型保険は，健康増進の努力が保険料 の割引につながる点が主たる特徵である。そのため, 自助努力により改善が 期待できない危険標識により，リスク細分化が進むとは考えづらい。

\section{6. 保険分類の観点からするリスク細分化}

前述のように健康増進型保険については, リスク細分化が批判されること はないと考えられる。もっとも, ICT の発達は健康増進型保険以外の保険 にも影響を及ぼす。そこで最後に，前述の原則および道德観から認められた 危険標識に該当していても，リスク細分化が規制される場合について，考察 してみたい。規制の導入にあたっては，その保険が果たす社会的な意義から 慎重に検討される必要があるが，本稿では，保険論における伝統的な区分を 糸口に，人保険を対象にこの規制について検討しておきたい。

保険の区分のひとつに公保険と私保険の区分がある ${ }^{49)}$ 。前者はなんらかの

47）公衆衛生審議会 (1996)。

48）近藤 (2018), p. 446。

49）公保険と私保険は保険の区分法の一つである。論者により多少意味は異なる が，自賠責保険や地震保険以外の民間の保険会社が扱う保険が私保険であり， 社会保険が公保険であることに異論はない。例えば洲崎は「公保険とは，国そ の他の公共団体が公的な政策の実現手段として行う保険をいう」。「これに対し て私保険とは，純然たる私経済的見地から行われる保険をいう」とする（山 下・竹澒・洲崎・山本 (2019), pp. 18-19)。今井 =岡田=梅津では, 「「保険」 という言葉の中で，もっとも大きな分類は公保険とされる「社会保険」と，本 書の主たる対象となる私保険の分類と言うことになろう」(今井（2011），p.3）。 保険論における説明としては「国家または地方自治体などによる政策実現の手 
健康増進型保険が保険事業に与える影響について

政策実現のために利用される保険であり，社会保険はその典型的な例である。 一方，私保険はそれ以外の保険を指す。社会保険の中には労桨保険のような 例外はあるものの，平均保険料方式を採用する場合が多い。つまり，そもそ も保険料率はリスクを反映されていない。高リスク者が負担するはずの保険 料の一部を低リスク者が負担することが前提となっている。公的医療保険で あれば，全国民が加入できるようにすべきであるが，個別保険料式を採用す るならば，それが難しくなるからである。

それに対して私保険では保険料率はリスクを反映するのが当然である。私 保険のなかでも特に企業保険は，企業のリスク転嫁手段の一つであり，自助 努力そのものである。そのため, 技術的な制約がなければ内部補助は好まし くないから，個別保険料式保険が採用されている。

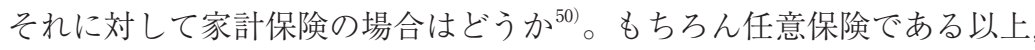
個別保険料方式で運営されるから，それぞれの支払う保険料（純保険料）は 自らに支払われる保険金の数学的期待值である。技術的な制約はあるものの， 給付反対給付均等の原則をつらぬく場合には, リスク細分型の保険が望まし いはずである。

しかしながら，現実には家計保険の場合であっても，技術的にさらに細分 化が可能であるにも拘わらず，細分化が規制されている保険がある。損害保 険の場合であるが，わが国の自動車保険においてはその細分化に制約が設け られている ${ }^{51)}$ 。年齢による純保険料率間の格差が3.0倍以下, 性別および地 域別の料率格差はいずれも1.5倍以内とされている。この料率の細分化に制

段として保険が利用される場合，当該保険を公保険と呼び，それ以外を私保険 石田と呼ぶ」（大谷（2012），p.54）。他にも鈴木は「国や地方公共団体などが 社会政策または経済政策実現の手段として保険を営む場合にこれを公保険とい い, これ以外の私保険（個人保険）と区別します」と説明する（鈴木（2000）, p. 42)。

50）ここで家計保険とは保険の区分法の一つで企業保険と異なり，家計が利用す る保険のことである。

51）保険業法施行規則第 12 条第 3 号八別表。 
限が設けられていることは, 内部補助の存在が容認されていることになる。 自賠責保険であれば，自動車事故被害者の救済という目的をもつ公保険の一 つであるから内部補助は問題とはならない ${ }^{52)}$ 。しかし任意の自動車保険は私 保険である。そのため内部補助は本来好ましくないはずであるが，任意保険 とはいえ，自動車保険（特に対人賠償責任保険）は実質的に自賠責保険を補 完しているからであろう。

自動車事故被害者の救済という目的を果たすためには，自賠責保険の保険 金額の限度額はあまりに低額である。死亡でさえ 3000 万が限度であり，最 も高い場合であっても，限度額は4000万円に過ぎない（介護を要する後遺障 害第一級)。それに対して対人事故の場合の損害賠償額は極めて高額となっ ている。認定総損害額は億単位が珍しくなく，5億円を超える場合さえあ る ${ }^{53)}$ 。そのため被保険者が賠償責任リスクを転嫁するためには，自賠責保険 だけでは不十分であり，任意の対人賠償責任保険に加入せざるをえない。

つまり，任意の対人賠償責任保険は自動車事故被害者の救済を目的とする 自賠責保険制度を実質的に補完している。それにも拘わらず，任意保険のリ スク細分化が進展してしまうならば被害者救済の機能を弱めることになって しまう。高リスクのドライバーの中には，高い保険料負担を嫌い，任意保険 から脱退してしまう者が必ず現れるからである。技術的な制約がないにも拘 わらずリスク細分化に限度が設けられ，ある程度の内部補助が容認されてい る理由は，公保険が果たす政策目的を阻害しないためと思われる。

それでは家計保険としての人保険はどうであろうか。わが国において家計 保険としての人保険は，第三者である被害者を救済する一面を持つ責任保険 とは状況が異なる。しかし公保険である社会保険を補完する性質を持つと一

52）洲崎は自賠責保険を私保険であるけれども「公保険としての色彩を相当程度 帯びている」とする（山下・竹湏・洲崎・山本 (2019), pp.19-20)。

53） 2011年の判決では 5 億2853万円が認められている（『2018年度自動車保険の 概況』。 
健康増進型保険が保険事業に与える影響について

般的に理解されている ${ }^{54)}$ 。そもそも社会保険だけでは生活保障に十分でない。 私的医療保険は公保険である公的医療保険を補完する役割を果たす。生命保 険も公的年金を補完するだけでなく，療養給付などを補完することから，公 的医療保険を補完している側面もある ${ }^{55)}$ 。死亡保険についても遺族年金を補 完し, 遺族の生活保障に資する。このように少なくとも家計保険である人保 険には，ある程度の公保険の補完的・補助的な性質を認めることができる。 このように家計保険としての人保険は公保険を補完していることから，それ が果たす目的を達成するためにある程度の内部補助を伴う規制の導入が容認 されるのではないか。

もっとも健康増進型保険の場合には, 公保険を補完することを理由として 料率区分が規制されることはなかろう。むしろ政策実現のために細分化が促 進される可能性さえある。前述のように，政策としての健康増進活動が行わ れる目的の一つには, 医療費の節減という側面がある。この節減は全国民に 受療を可能とさせる医療保険制度の持続可能性を高めるという意味がある。 つまり，健康増進型保険は公保険を支援するという一面を持つ。そのため， リスク細分化が望まれることはあっても，それが規制される可能性は少ない であろう。

\section{結びにかえて}

ICT の発達により登場した健康増進型保険は, 生活習慣病の防止に資す る保険である。生活習慣病の病因がすべて生活習慣に帰することはできない

54）生活保障システムという概念から説明されることもある。これは生活に関わ る個人や家族を保護する諸制度を一つのシステムと捉える概念である。この場 合に生活保障システムは社会保障, 企業保障および個人保障というサブシステ ムからなる。私的医療保険などの個人保障は「社会保障・公的保障を補完・代 替する」ものと捉えられている。下和田 (2014), pp. 316-321。

55）金融庁の報告書でも老後の生活に公的年金が十分ではないことが明記された （金融審議会市場ワーキング・グループ報告書『高齢社会における資産形成・ 管理』令和元年 6 月 3 日)。 
とはいえ, 個々人の努力が予防に重要であることはいうまでもない。健康増 進型保険は被保険者の健康増進へのモチベーションを高めるという点で好ま しい保険といえる。

(筆者は香川大学教授)

\section{参考文献・資料}

IAIS[2017] Fin Tech Developments in the Insurance Industry.

IoMT 学会 (https://iomt.or.jp : 2019/7/23 閲覧)。

石田満 [2003] 『損害保険料率算出団体に関する法律』新版第一版, 損害保険事業 総合研究所。

今井薰・岡田豊基・梅津昭彦 [2011]『レクチャー新保険法』法律文化社。

上野雄史 [2019]「InsureTech が生命保険業に及ぼす影響とその課題」『生命保険 論集』208号 (別冊)。

大谷孝一編著 [2012] 『保険論（第三版）』成文堂。

加藤浩晃 [2018］『医療4.0第四次産業革命の医療～未来を描く30人の意思による 2030年への展望〜』日経メディカル。

加藤洋輝・桜井駿 [2016] 『決定版フィンテック金融革命の全貌』東洋経済新報社。 熊沢由弘[2018a］「「健康分野」における最近の政府・関係省庁の取組みと生命保 険会社の動向」『共済総研レポート』No.158。

熊沢由弘 $[2018 b] \Gamma\ulcorner$ 健康増進型保険」の個別商品の特徵と JA 共済の「健康分野」

の取組みについての考察」『共済総研レポート』No.159。

肥塚肇雄 [2019]「デー夕駆動型社会におけるリスクの変容と保険契約の課題」『生 命保険論集』第206号。

近藤克則 [2018］「座長趣旨説明（医研シンポジウム2017講演録 健康な社会づくり

をめざして：健康自己責任論を超えて何をなすべきか)」『医療と社会』27(4)。 厚生省公衆衛生審議会 [1996] 『生活習慣に着目した疾病対策の基本的方向性につ いて（意見具申)』厚生労働省（https://www.mhlw.go.jp/www1/houdou/0812/ 1217-4.html : 2020/5/8 閲覧)

下和田功編 $[2014]$ 『はじめて学ぶリスクと保険 [第 4 版]』有斐閣。 鈴木辰紀編著 $[2000]$ 『保険論 (第十版)』成文堂。

生命保険新実務講座編集委員会・財団法人生命保険文化研究所 [1991] 『生命保険 新実務講座 7 法律』有斐閣。

大和総研編著 [2018］『FinTech と金融の未来』日経 BP 社。

東洋経済新報社『生保・損保特集2019年版』東洋経済新報社。 
健康増進型保険が保険事業に与える影響について

日本保険医学会監訳[2003] 『保険医学原書第 4 版コンパクト版』南江堂。

ハリントン = ニーハウス著, 米山高生 =箸方幹逸監訳 $[2005]$ 『保険とリスクマネ

ジメント』東洋経済新報社。

福田洋 [2018］「職域ヘルスプロモーション (WHP)の変遷と成果一有効で感謝され

る働き盛り世代の健康支援とヘルスリテラシーの向上を目指して」『日健教誌』

第26巻第 1 号。

ブラウン, $\mathrm{H}$ 著, 水島一也監訳 $[1983]$ 『生命保険史』明治生命100周年記念刊行会。 ボストンコンサルティンググループ保険グループ[2018］『デジタル革命時代にお

ける保険会社経営』金融財政事情研究会。

真野俊樹 [2005] 『健康マーケティング』日本評論社。

水島一也[2006] 『現代保険経済第八版』千倉書房。

武藤伸行 [2019］「生命保険業界におけるインシュアテックの取組み等」『令和元年

度日本保険学会大会レジュメ』。

安井信夫 [1997]『人保険論』成文堂。

山下友信 ·竹䌸修・洲崎博史・山本哲生[2019] 『保険法第 4 版』有斐閣。

米山高生 [2017]「マイナスのモラルハザード-契約法で想定していなかった保険商 品の登場」『保険学雑誌』第637号。 